\title{
Parenteral Glycerol Enhances Gluconeogenesis in Very Premature Infants
}

\author{
AGNETA L. SUNEHAG \\ Children's Nutrition Research Center, USDA/ARS, Baylor College of Medicine, Houston, Texas, U.S.A.
}

\begin{abstract}
We have previously demonstrated that very premature infants receiving total parenteral nutrition maintain normoglycemia primarily by glucose produced via gluconeogenesis and that the lipid emulsion is most important in supporting gluconeogenesis. It is, however, not clear whether this is a result of the glycerol or the fatty acid constituent. The purpose of the present study was to determine the effect of intravenous supplemental glycerol alone on glucose production and gluconeogenesis. Twenty infants (birth weight, $1014 \pm 32 \mathrm{~g}$; gestational age, $27 \pm 1 \mathrm{wk}$ ) were studied on $\mathrm{d} 4 \pm 1$ (mean $\pm \mathrm{SE}$ ). All infants received glucose at $17 \mu \mathrm{mol} / \mathrm{kg} \cdot \mathrm{min}$ for $9 \mathrm{~h}$ (after an initial study hour with $33 \mu \mathrm{mol} / \mathrm{kg} \cdot \mathrm{min})$. Eight infants received no additional substrate during the study, and 12 infants received supplemental glycerol at $5(n=6)$ or $10 \mu \mathrm{mol} / \mathrm{kg} \cdot \min (n=6)$ over the last $5 \mathrm{~h}$ of study. In infants receiving glucose alone, between period 1 (study hours 4-5) and period 2 (study hours 9-10), rates of
\end{abstract}

ABSTRACT

glucose production ([U- $\left.{ }^{13} \mathrm{C}\right]$ glucose $)$ decreased from $12.9 \pm 1.2$ to $7.4 \pm 0.9 \mu \mathrm{mol} / \mathrm{kg} \cdot \mathrm{min}(p<0.01)$. This was the result of decreased glycogenolysis but no change in gluconeogenesis ([U$\left.{ }^{13} \mathrm{C}\right]$ glucose mass isotopomer distribution analysis) $(5.1 \pm 0.6$ versus $5.7 \pm 0.4 \mu \mathrm{mol} / \mathrm{kg} \cdot \mathrm{min}$ ) (ns). Glycerol infusion at 5 and $10 \mu \mathrm{mol} / \mathrm{kg} \cdot \mathrm{min}$, respectively, maintained glucose production (despite comparable decrease in glycogenolysis) by increasing gluconeogenesis from $4.3 \pm 0.2$ to $6.3 \pm 0.5(p<0.03)$, and 6.0 \pm 0.7 to $8.8 \pm 0.8 \mu \mathrm{mol} / \mathrm{kg} / \mathrm{min}(p<0.01)$. In very premature infants, parenteral glycerol enhances gluconeogenesis and attenuates time dependent decrease in glucose production. (Pediatr Res 53: 635-641, 2003)

Abbreviations
MIDA, mass isotopomer distribution analysis
TPN, total parenteral nutrition

The clinical outcome of premature infants has improved dramatically over the past two decades. As a result, in the United States today, the majority of infants with birth weights of $1500 \mathrm{~g}$ or less survive the neonatal period (1). This has led to increased need for long-term nutritional support to sustain normal growth and development. In extremely premature infants, enteral feedings are often not initiated until the end of the first postnatal week, or even later $(2,3)$. As a result, these infants are totally dependent on parenteral nutrition during their first several days of life. On a body weight basis, premature infants have high glucose demands because of their large brain to body weight ratio $(4,5)$. During periods of inadequate glucose or energy intake, the glycogen stores are gradually

Received April 25, 2002; acceped August 13, 2002.

Correspondence: Agneta L. Sunehag, Children's Nutrition Research Center, 1100 Bates Street, Houston TX, 77030, U.S.A; e-mail: asunehag@bcm.tmc.edu

Supported by National Institutes of Health (NIH) grant RO1 HD 37857; United States Department of Agriculture Cooperative Agreement \#58-6250-6-001; and the General Clinical Research Center, National Center for Research Resources, NIH MO1-RR-001888 and NIH RO1 DK 55478.

This work is a publication of the USDA/ARS Children's Nutrition Research Center, Department of Pediatrics, Baylor College of Medicine, Houston, TX, U.S.A. The contents of this publication do not necessarily reflect the views of policies of the U.S. Department of Agriculture, nor does mention of trade names, commercial products, or organizations imply endorsement from the U.S. Government.

DOI: 10.1203/01.PDR.0000054774.90893.0F diminished and gluconeogenesis from glycerol, pyruvate, lactate, and several amino acids, e.g. alanine and glutamine, becomes the primary source of glucose production $(6,7)$.

Maintenance of normoglycemia is often problematic in small premature neonates. These infants have small glycogen, fat, and protein stores (4) and are, therefore, at high risk of hypoglycemia. To prevent hypoglycemia and provide a sufficient energy intake, parenteral glucose is introduced immediately after delivery, and parenteral amino acids and lipids are added within 1 or $2 \mathrm{~d}$ of birth, thus providing important additional sources of energy. However, when glucose is administered at rates exceeding normal glucose turnover rates, hyperglycemia frequently occurs, particularly in the smallest infants and in infants with sepsis and other severe illnesses $(8-12)$.

The physiologic control of glucose production and gluconeogenesis from endogenous and exogenous sources is not completely understood in the premature infant. In healthy, fasting term infants, lactate, pyruvate, alanine, and glycerol (13-17) contribute to glucose production within a few hours of birth. In addition, we have demonstrated that endogenous glycerol, a lipolytic product of peripheral triacylglycerol hydrolysis, can serve as an important gluconeogenic substrate during the first $24 \mathrm{~h}$ of life in extremely premature infants (18). 
Parenteral lipids (Intralipid®, Fresenius KABI; Uppsala, Sweden) have been reported to increase blood glucose concentrations in premature infants (19-22), but the specific mechanism by which this occurs in these infants remains to be determined. We have previously demonstrated that infants born at $\leq 29$ wk of gestation, receiving a reduced glucose supply but adequate lipid and amino acid substrate by vein, maintained normoglycemia as a result of significant production of glucose via the gluconeogenic pathway (7). Intralipid can potentially stimulate gluconeogenesis in two ways: by providing gluconeogenic carbon substrate as glycerol and by delivery of fatty acids that, upon oxidation, drive gluconeogenesis by generating acetyl coenzyme A and the reducing agents NAD/ $\mathrm{NADH}$. The design of the previous study did not allow us to determine the separate effects of the glycerol and fatty acid components of Intralipid on gluconeogenesis.

Thus, the purposes of the present study were to determine in very premature infants 1 ) the time course of glucose production from gluconeogenesis and glycogenolysis under conditions requiring hepatic glucose production, and 2) the effect of supplemental intravenouse glycerol alone (i.e. without infusion of concomitant FFA) on these parameters. We hypothesized that supplemental glycerol alone would enhance gluconeogenesis in these infants.

\section{RESEARCH DESIGN AND METHODS}

Subjects. All protocols were reviewed and approved by the Institutional Review Board for Human Research at Baylor College of Medicine in Houston, TX, U.S.A. The subjects were recruited from the neonatal intensive care unit at Texas Children's Hospital. Parents of eligible infants were approached after approval from the attending physician. The details of the study were explained to the parent(s). If necessary, they were given up to 48 additional hours to study the consent form before agreeing to sign it. The infants were enrolled only after written consent was obtained from at least one parent.

Eligible infants were those with birth weights $\geq 750 \mathrm{~g}$ and appropriately sized for a gestational age of $\leq 29 \mathrm{wk}(23,24)$. None had Apgar scores $<5$ at $5 \mathrm{~min}$, congenital malformations, or any sign of other disease e.g. sepsis. None of the mothers was diabetic. Further excluded were infants requiring $>30 \%$ oxygen by ventilators and infants treated with insulin prior or at time of the study or dopamine $>5 \mu \mathrm{g} / \mathrm{kg} \cdot \mathrm{min}$ at time of the study. Only infants with both umbilical vein and artery catheters in place were included.

Twenty infants, nine girls and 11 boys, were studied. Of these, six were white, six were black, and eight were Hispanic. Tables 1 and 2 show demographic and clinical characteristics of these infants. The majority of the mothers $(15 / 20)$ had received antenatal steroids (betamethasone, one to five doses, $12 \mathrm{mg}$ each). In our previous study (7), antenatal steroids had no effect on glucose production or gluconeogenesis. The infants were born after $27 \pm 1$ wk of gestation (mean \pm SE) (Table 1). By definition, they were appropriate size for gestational age $(23,24)$, with birth weights averaging $1014 \pm 32 \mathrm{~g}$ (Table 1).

According to the nursery's clinical practice guidelines, all of the infants had received two to four doses of surfactant [Survanta (beractant), Abbott Laboratories, Abbott Park, IL, U.S.A.] before the study. All infants had stable heart rate and blood pressure. At the time of the study (on d $4 \pm 1$ of life), eight infants were intubated and ventilated, and 12 infants were treated with continuous positive airway pressure (Table 2). All had normal oxygenation (92-98\%) and acid base status (Table 2). In all infants, the period from birth to start of the study was otherwise uneventful. Twelve infants were on prophylactic treatment with antibiotics because of premature rupture of membranes, but none had any clinical signs or laboratory evidence of sepsis.

Twelve infants were being treated with caffeine $(5 \mathrm{mg} / \mathrm{kg} \cdot \mathrm{d})$ and five infants were receiving a low dose of dopamine (Table 2). Each of these infants had stable blood pressure and was in the process of being weaned off the dopamine. Infants receiving caffeine or dopamine did not differ from those not receiving these drugs with regard to any studied variable and, in addition, each infant was his or her own control. We have also previously demonstrated that measures of glucose concentration, glucose production, and gluconeogenesis in premature infants were not affected by caffeine or a low dose of dopamine (data not shown).

Administration of TPN and tracer solutions. Both solutions were administered via umbilical venous catheters already in place for clinical care purposes. All isotopes were administered by syringe infusion pumps (Medinfusion 2010, Medex, Inc., Duluth, GA, U.S.A.).

Tracers. $\left[\mathrm{U}-{ }^{13} \mathrm{C}\right.$ ]glucose $\left(98+\right.$ atom $\left.\%{ }^{13} \mathrm{C} ; 93.8 \%{ }^{13} \mathrm{C}_{6}\right)$, $\left[2-{ }^{13} \mathrm{C}\right]$ glycerol $\left(99\right.$ atom $\%{ }^{13} \mathrm{C}$ ), and $\left[{ }^{2} \mathrm{H}_{5}\right]$ glycerol (used as internal standard) (98 atom $\%{ }^{2} \mathrm{H} ; 90 \%{ }^{2} \mathrm{H}_{5}$ ) were purchased from Cambridge Isotope Laboratories, Andover, MA, U.S.A. The tracers were tested for sterility and pyrogenicity, dissolved in isotonic saline, and prepared for intravenous infusion by the research pharmacy at Texas Children's Hospital.

Parenteral nutrition. None of the infants had received any enteral feeding. All infants were receiving TPN providing glucose at $14.0 \pm 0.5 \mathrm{~g} / \mathrm{kg} \cdot \mathrm{d}$, lipids (Intralipid 20\%) at $1.8 \pm$ $0.3 \mathrm{~g} / \mathrm{kg} \cdot \mathrm{d}$, and protein (TrophAmine ${ }^{\circledR}, \mathrm{McGaw}$, Irvine, CA,

Table 1. Subject characteristics

\begin{tabular}{lccrr}
\hline \multicolumn{1}{c}{ Subjects } & No. & Gestation age (wk) & Birth weight (g) & Postnatal age (d) \\
\hline Glucose alone & 8 & $28 \pm 1$ & $1039 \pm 68$ & $4 \pm 1$ \\
Glucose + Glyc 5 & 6 & $28 \pm 1$ & $1025 \pm 15$ & $4 \pm 1$ \\
Glucose + Glyc 10 & 6 & $26 \pm 1$ & $971 \pm 58$ & $5 \pm 1$ \\
\hline
\end{tabular}

The glucose infusion rate in all infants was $\sim 17 \mu \mathrm{mol} / \mathrm{kg} / \mathrm{min}(\sim 3 \mathrm{mg} / \mathrm{kg} / \mathrm{min})$. The glucose alone group $(n=8)$ received only glucose for $10 \mathrm{~h}$, whereas the glucose + Glyc 5 and glucose + Glyc 10 groups received supplemental glycerol at $5(n=6)$ or $10 \mu \mathrm{mol} / \mathrm{kg} / \mathrm{min}(n=6)$, respectively, during the final $5 \mathrm{~h}$ of the 10-h study period. 
Table 2. Clinical characteristics

\begin{tabular}{|c|c|c|c|c|c|c|c|c|c|}
\hline Subjects & No. & $\begin{array}{l}\text { Antenatal } \\
\text { steroids* }\end{array}$ & Phenobarbital $\dagger$ & Dopamine & Caffeine $\ddagger$ & $\begin{array}{l}\text { CPAP (no.) } \\
\text { PEEP } \\
\left(\mathrm{cm} \mathrm{H}_{2} \mathrm{O}\right)\end{array}$ & $\begin{array}{c}\text { Assisted } \\
\text { ventilation (no.) } \\
\text { PIP/PEEP } \\
\left(\mathrm{cm} \mathrm{H}_{2} \mathrm{O}\right)\end{array}$ & $\mathrm{FiO}_{2}$ & $\mathrm{pH} / \mathrm{PCO}_{2}$ \\
\hline Glucose + Glyc 5 & 6 & 5 & 0 & 0 & 4 & $\begin{array}{c}6 \\
(10)\end{array}$ & 0 & $0.25 \pm 0.02$ & $7.30 \pm 0.02 / 41 \pm 2$ \\
\hline
\end{tabular}

The glucose infusion rate in all infants was $\sim 17 \mu \mathrm{mol} / \mathrm{kg} / \mathrm{min}(\sim 3 \mathrm{mg} / \mathrm{kg} \cdot \mathrm{min})$. The glucose alone group $(n=8)$ received only glucose for $10 \mathrm{~h}$, whereas the glucose + Glyc 5 and glucose + Glyc 10 groups received supplemental glycerol at $5(n=6)$ or $10 \mu \mathrm{mol} / \mathrm{kg} \cdot \mathrm{min}(n=6)$, respectively, during the final $5 \mathrm{~h}$ of the 10-h study period.

* Betamethasone, one to four doses; $\dagger$ being weaned; $\$$ maintenance dose, i.e., $5 \mathrm{mg} / \mathrm{kg} / \mathrm{d}$.

CPAP, continuous positive airway pressure; PEEP, positive end-expiratory pressure; PIP, positive inspiratory pressure (actual pressures given within parenthesis); $\mathrm{FiO}_{2}$, fraction of inspired oxygen.

U.S.A.) at $2.7 \pm 0.1 \mathrm{~g} / \mathrm{kg} \cdot \mathrm{d}$ until the studies commenced. This TPN provided a total fluid intake of $113 \pm 4 \mathrm{~mL} / \mathrm{kg} / \mathrm{d}$ and 75 $\pm 4 \mathrm{kcal} / \mathrm{kg} \cdot \mathrm{d}$. There were no differences among the groups regarding the composition of the prestudy TPN. Thus, the prestudy Intralipid infusion rates were $1.5 \pm 0.2 \mathrm{~g} / \mathrm{kg} \cdot \mathrm{d}$ and 1.7 $\pm 0.4 \mathrm{~g} / \mathrm{kg} \cdot \mathrm{d}(\mathrm{ns})$ in the infants receiving glucose alone and glucose plus glycerol (glucose + Glyc), respectively.

The studies lasted for $10 \mathrm{~h}$ in all infants. At the start of the studies (time 0 ), the glucose infusion rate was reduced stepwise to diminish acute counter-regulatory hormone responses. This approach consisted of a reduction of the glucose infusion rate from the prestudy rate of $54 \pm 2 \mu \mathrm{mol} / \mathrm{kg} \cdot \min (9.7 \pm 0.4$ $\mathrm{mg} / \mathrm{kg} \cdot \mathrm{min})$ to $33 \mu \mathrm{mol} / \mathrm{kg} \cdot \mathrm{min}(6 \mathrm{mg} / \mathrm{kg} \cdot \mathrm{min})$ over the first study hour and then to $\sim 17 \mu \mathrm{mol} / \mathrm{kg} \cdot \mathrm{min}(3 \mathrm{mg} / \mathrm{kg} \cdot \mathrm{min})$ (approximately one half of basal glucose turnover rate) for the remaining 9 study hours (see "Measurements of parameters of glucose metabolism").

In one group of infants (denoted "glucose alone") $(n=8)$, both Intralipid and TrophAmine were discontinued at time 0 . In other words, from $t=1 \mathrm{~h}$, these infants received only glucose at $\sim 17 \mu \mathrm{mol} / \mathrm{kg} \cdot \min$ for $9 \mathrm{~h}$.

In a second group of infants (denoted "glucose + Glyc") (n $=12$ ), both Intralipid and TrophAmine were discontinued at time 0 . Thereafter, the infants received the same glucose infusion as the "glucose alone" group during the 10-h study period. However, during the final 5 study hours, supplemental exogenous glycerol was infused at either $5 \mu \mathrm{mol} / \mathrm{kg} \cdot \mathrm{min}$ ("glucose + Glyc 5") $(n=6)$ or at $10 \mu \mathrm{mol} / \mathrm{kg} \cdot \mathrm{min}$ ("glucose + Glyc 10") $(n=6)$.

At the end of the study period, the infant's routine TPN regimen was restored. Thus, on the day of study, the infants received a total fluid volume of $111 \pm 2 \mathrm{~mL} / \mathrm{kg} \cdot \mathrm{d}$ and a total energy intake of $57 \pm 1 \mathrm{kcal} / \mathrm{kg} \cdot \mathrm{d}$. The total fluid volume did not differ from that provided during the day preceding the study. The energy intake during the study day was somewhat lower than during the day preceding the study but exceeded the energy needs determined during the first week of life in similar infants $(25,26)$.

Blood sampling. All blood samples were drawn from umbilical artery catheters already in place for clinical care purposes. The umbilical artery catheters were kept patent with isotonic saline both before and during the study period $(0.2$ $\mathrm{mL} / \mathrm{h}$ with $1 \mathrm{U}$ heparin $/ \mathrm{mL}$ ). Samples for analysis of blood glucose concentration, ${ }^{13} \mathrm{C}$ mass isotopomer distribution of plasma glucose, and ${ }^{13} \mathrm{C}$ enrichment in plasma glycerol were obtained before start of the tracer infusions (baseline), and then at $4,4.5$, and $5 \mathrm{~h}$ (denoted period 1) and 9, 9.5, and $10 \mathrm{~h}$ (denoted period 2) in all infants. Plasma insulin concentrations were measured at the end of the study and, in addition, between study hours 4 and 5 (pooled samples).

In addition, blood glucose concentrations were measured hourly at the bedside to ensure that normoglycemia (blood glucose $\geq 40 \mathrm{mg} / \mathrm{dL}$ or $\geq 2.2 \mathrm{mM}$ ) was maintained (27-29). In two infants, described below, the glucose infusion rate was increased to maintain the blood glucose concentration $>40$ $\mathrm{mg} / \mathrm{dL}(>2.2 \mathrm{mM})$. In one infant ("glucose alone" group), the infusion rate of glucose was increased by $5.0 \mu \mathrm{mol} / \mathrm{kg} \cdot \min (0.9$ $\mathrm{mg} / \mathrm{kg} \cdot \mathrm{min}$ ) after the infant's blood glucose value decreased from 47 to $41 \mathrm{mg} / \mathrm{dL}$ (i.e. 2.6 to $2.3 \mathrm{mM}$ ) between study hours 5 and 6. This increase in the glucose infusion rate resulted in a stabilization of the blood glucose at $50 \mathrm{mg} / \mathrm{dL}(2.8 \mathrm{mM})$. A second infant ("glucose + Glyc 10" group) had one blood glucose value of $37 \mathrm{mg} / \mathrm{dL}(2.0 \mathrm{mM})$ while receiving glucose alone. After an increase in the glucose infusion rate by 2.2 $\mu \mathrm{mol} / \mathrm{kg} \cdot \mathrm{min}(0.4 \mathrm{mg} / \mathrm{kg} \cdot \mathrm{min})$, the blood glucose concentration increased instantly and remained stable at $54 \mathrm{mg} / \mathrm{dL}(3.0 \mathrm{mM})$ during period 1 , and increased further to $69 \mathrm{mg} / \mathrm{dL}(3.8 \mathrm{mM})$ during period 2 .

The total blood volume withdrawn in each of these studies was $\leq 2.9 \mathrm{~mL}$, which is within the limits established by the Institutional Review Board at Baylor College of Medicine. Sample volume restrictions precluded analyses of FFA and ketone body concentrations.

Analyses. Blood glucose concentrations were measured using a glucose analyzer (YSI 2300 Stat Plus, YSI Inc, Yellow Springs, OH, U.S.A.), and plasma insulin concentrations using a conventional RIA (Linco, St. Charles, MO, U.S.A.) with a detection limit of $0.5 \mu \mathrm{U} / \mathrm{mL}$. The mass isotopomer distribution of glucose during infusion of $\left[\mathrm{U}-{ }^{13} \mathrm{C}\right]$ glucose, the enrichments of $\left[2-{ }^{13} \mathrm{C}\right]$ glycerol, and the internal standard $\left[{ }^{2} \mathrm{H}_{5}\right]$ glycerol were measured by gas chromatography mass spectrometry as described previously (7). 
Measurements of parameters of glucose metabolism. Rates of total glucose appearance in plasma, glucose production, and gluconeogenesis were measured between study hours 4 and 5 (period 1) and 9 and 10 (period 2) using the $\left[\mathrm{U}-{ }^{13} \mathrm{C}\right]$ glucose tracer $(6,7)$. Total plasma glucose appearance rate was calculated from the plasma enrichment of $\left[\mathrm{U}_{-}{ }^{13} \mathrm{C}\right]$ glucose, and gluconeogenesis was estimated using MIDA of plasma glucose (6), as described in detail previously (7).

We have demonstrated that $\left[\mathrm{U}_{-}{ }^{13} \mathrm{C}\right]$ glucose MIDA provided an estimate of total gluconeogenesis identical to that measured using deuterium oxide in healthy young adults studied after a 66-h fast (30). Because the deuterium oxide method requires large blood samples (31), we were not able to directly compare the methods in preterm infants.

In all infants, an infusion of $\left[\mathrm{U}_{-}{ }^{13} \mathrm{C}\right]$ glucose, metabolically equivalent to natural glucose, was begun at time 0 and continued throughout the study period at $16.7 \mu \mathrm{mol} / \mathrm{kg} \cdot \min (3.0$ $\mathrm{mg} / \mathrm{kg} \cdot \mathrm{min})$. During the first hour of the infusion period, the infants received an additional $16.7 \mu \mathrm{mol} / \mathrm{kg} \cdot \mathrm{min}(3 \mathrm{mg} / \mathrm{kg} \cdot \mathrm{min})$ of natural glucose. This infusion was discontinued after the first study hour and, thereafter, $\left[\mathrm{U}_{-}{ }^{13} \mathrm{C}\right]$ glucose represented the entire source of exogenous glucose throughout the study, except in one infant in the "glucose alone" and one in the "glucose + Glyc 10" group, who received an additional 5.0 and $2.2 \mu \mathrm{mol} / \mathrm{kg} \cdot \min (0.9$ and $0.4 \mathrm{mg} / \mathrm{kg} \cdot \mathrm{min})$, respectively, of unlabeled glucose to maintain blood glucose above $2.2 \mathrm{mM}$ (see above). Thus, in the "glucose alone" group, the total glucose infusion rate was $17.3 \pm 0.7 \mu \mathrm{mol} / \mathrm{kg} \cdot \min (3.1 \pm 0.1$ $\mathrm{mg} / \mathrm{kg} \cdot \mathrm{min})$ and in the "glucose + Glyc" group $17.2 \pm 0.3$ $\mu \mathrm{mol} / \mathrm{kg} \cdot \min (3.1 \pm 0.1 \mathrm{mg} / \mathrm{kg} \cdot \mathrm{min})$ (Table 3$)$.

Measurements of plasma concentrations and appearance rates of glycerol. Glycerol turnover was measured using $\left[2-{ }^{13} \mathrm{C}\right]$ glycerol $(15-18)$. The infusion of this tracer was started at time 0 and continued throughout the entire 10-h study period at $0.15 \pm 0.01 \mu \mathrm{mol} / \mathrm{kg} \cdot \mathrm{min}(0.01 \pm 0.01 \mathrm{mg} / \mathrm{kg} \cdot \mathrm{min})$, a rate that would not contribute to overall glycerol turnover or MIDA analyses of glucose. Plasma glycerol concentrations were measured by reverse isotope dilution technique using $\left[{ }^{2} \mathrm{H}_{5}\right]$ glycerol as an internal standard (7).

Calculations. Total plasma glucose appearance rates were calculated from the ${ }^{13} \mathrm{C}_{6}$-enrichment of glucose during approximate steady state (defined by a coefficient of variation of $<10 \%$ ), i.e. between study hours 4 and 5 (period 1) and 9 and 10 (period 2) using established isotope dilution equations (32, 33)

$$
\text { Total plasma glucose appearance rate }=\left(\mathrm{E}_{\mathrm{i}} / \mathrm{E}_{\mathrm{p}}\right) \times \mathrm{I}
$$

where $E_{i}$ is the ${ }^{13} C_{6}$-enrichment of the infusate; $E_{p}$ is the ${ }^{13} \mathrm{C}_{6}$-enrichment in plasma, and $\mathrm{I}$ is the infusion rate of $\left[\mathrm{U}-{ }^{13} \mathrm{C}\right]$ glucose $(\mu \mathrm{mol} / \mathrm{kg} \cdot \mathrm{min})$. Under steady state conditions, glucose appearance rate $=$ glucose disappearance (utilization) rate

\section{Glucose production rate$$
=\text { Total plasma glucose appearance rate }- \text { GIR }
$$

where GIR is the glucose infusion rate, which is the sum of all labeled and unlabeled glucose infused, i.e. $\left[\mathrm{U}-{ }^{13} \mathrm{C}\right]$ glucose + natural glucose.

Fractional gluconeogenesis, i.e. gluconeogenesis in percentage of total plasma glucose appearance rate, was calculated using $\left[\mathrm{U}-{ }^{13} \mathrm{C}\right]$ glucose $\operatorname{MIDA}(6,7)$

$$
\text { Fractional GNG }=\left(\sum_{1}^{5} M_{i} \sum_{1}^{6} M_{i}\right) \times\left(\sum_{1}^{5} C_{i}^{12} C_{1}^{5} \sum_{1}^{13} C_{i}\right)
$$

where $\mathrm{M}_{\mathrm{i}}$ are the isotopomers of glucose, i.e. glucose molecules labeled with ${ }^{13} \mathrm{C}$ on 1 through 6 of their carbons; ${ }^{13} \mathrm{C}_{\mathrm{i}}$ and ${ }^{12} \mathrm{C}_{\mathrm{i}}$ are the ${ }^{13} \mathrm{C}$ and ${ }^{12} \mathrm{C}$ in labeled gluconeogenic molecules, i.e. glucose molecules labeled on 1 through 5 of their carbons (6)

\begin{tabular}{|c|c|c|c|c|}
\hline & & $\begin{array}{l}\text { Glucose } \\
\text { alone }\end{array}$ & $\begin{array}{c}\text { Glucose }+ \\
\text { Glyc } 5\end{array}$ & $\begin{array}{c}\text { Glucose }+ \\
\text { Glyc } 10\end{array}$ \\
\hline \multirow[t]{2}{*}[\mathrm{U}-{}^{13}\mathrm{C}]{ glucose $(\mu \mathrm{mol} / \mathrm{kg} \cdot \mathrm{min})$} & Period 1 & $16.7 \pm 0$ & $16.7 \pm 0$ & $16.7 \pm 0$ \\
\hline & Period 2 & $16.7 \pm 0$ & $16.7 \pm 0$ & $16.7 \pm 0$ \\
\hline \multirow[t]{2}{*}{ Total glucose infused $(\mu \mathrm{mol} / \mathrm{kg} \cdot \mathrm{min})$} & Period 1 & $17.3 \pm 0.7$ & $17.3 \pm 0.4$ & $17.1 \pm 0.4$ \\
\hline & Period 2 & $17.3 \pm 0.7$ & $17.3 \pm 0.4$ & $17.1 \pm 0.4$ \\
\hline \multirow[t]{2}{*}{ Glucose $\mathrm{Ra}(\mu \mathrm{mol} / \mathrm{kg} \cdot \mathrm{min})$} & Period 1 & $29.6 \pm 1.2 *$ & $26.9 \pm 1.1$ & $27.6 \pm 1.2$ \\
\hline & Period 2 & $24.8 \pm 1.3$ & $25.3 \pm 1.1$ & $26.3 \pm 0.8$ \\
\hline \multirow[t]{2}{*}{$\operatorname{GPR}(\mu \mathrm{mol} / \mathrm{kg} \cdot \mathrm{min})$} & Period 1 & $12.9 \pm 1.2^{*}$ & $9.9 \pm 1.2$ & $10.4 \pm 1.3$ \\
\hline & Period 2 & $7.4 \pm 0.9$ & $8.3 \pm 1.2$ & $9.1 \pm 0.9$ \\
\hline \multirow[t]{2}{*}{ Fractional GNG \% of glucose Ra } & Period 1 & $17.3 \pm 2.0^{*}$ & $15.9 \pm 0.6^{*}$ & $21.9 \pm 2.2^{*}$ \\
\hline & Period 2 & $23.2 \pm 1.5$ & $24.7 \pm 1.2$ & $33.3 \pm 2.5$ \\
\hline \multirow[t]{2}{*}{ GNG rate $(\mu \mathrm{mol} / \mathrm{kg} \cdot \mathrm{min})$} & Period 1 & $5.1 \pm 0.6$ & $4.2 \pm 0.2 \dagger$ & $6.0 \pm 0.6^{*}$ \\
\hline & Period 2 & $5.7 \pm 0.4$ & $6.3 \pm 0.5$ & $8.8 \pm 0.8$ \\
\hline \multirow[t]{2}{*}{ Glycogenolytic rate $(\mu \mathrm{mol} / \mathrm{kg} \cdot \mathrm{min})$} & Period 1 & $7.8 \pm 1.2 *$ & $5.5 \pm 1.2 \dagger$ & $4.4 \pm 1.1^{*}$ \\
\hline & Period 2 & $1.7 \pm 0.8$ & $2.0 \pm 0.8$ & $0.3 \pm 0.7$ \\
\hline \multirow[t]{2}{*}{ Glycerol turnover $(\mu \mathrm{mol} / \mathrm{kg} \cdot \mathrm{min})$} & Period 1 & $7.1 \pm 1.5$ & $2.7 \pm 1.0 \dagger$ & $1.6 \pm 0.2 *$ \\
\hline & Period 2 & $8.1 \pm 1.5$ & $5.9 \pm 0.4$ & $10.5 \pm 0.2$ \\
\hline
\end{tabular}

Table 3. Glucose and glycerol kinetics in the three study groups

The glucose alone group $(n=8)$ received only glucose for $10 \mathrm{~h}$, whereas the glucose + Glyc 5 and glucose + Glyc 10 groups received supplemental glycerol at $5(n=6)$ or $10 \mu \mathrm{mol} / \mathrm{kg} \cdot \min (n=6)$, respectively, during the final $5 \mathrm{~h}$ of the 10 -h study period.

Glucose Ra, total plasma glucose appearance rate; GPR, glucose production rate; GNG, gluconeogenesis.

$* p<0.01$ (study period $1 v s$ study period 2); $\dagger p<0.05$ (study period 1 vs study period 2). 
Gluconeogenic rate $=$ Fractional gluconeogenesis

$\times$ total plasma glucose appearance rate.

Glycogenolysis $=$ Glucose production rate

$$
\text { - Gluconeogenic rate }
$$

Total plasma glycerol appearance rates were calculated from the ${ }^{13} \mathrm{C}_{1}$-enrichment of glycerol during approximate steady state (defined by a coefficient of variation of $<10 \%$ ), i.e. between study hours 4 and 5 (period 1) and 9 and 10 (period 2) using established isotope dilution equations (15-18)

$$
\text { Total plasma glycerol appearance rate }=\left(\mathrm{E}_{\mathrm{i}} / \mathrm{E}_{\mathrm{p}}\right) \times \mathrm{I}
$$

where $\mathrm{E}_{\mathrm{i}}$ is the enrichment of the $\left[2-{ }^{13} \mathrm{C}\right]$ glycerol tracer; $\mathrm{E}_{\mathrm{p}}$ is the ${ }^{13} \mathrm{C}$ glycerol enrichment in plasma, and $\mathrm{I}$ is the infusion rate of the $\left[2-{ }^{13} \mathrm{C}\right]$ glycerol tracer.

Absolute changes in rates of glucose production, glycogenolysis, and gluconeogenesis were calculated as the difference between period 2 and period 1 values for each parameter.

Statistical analyses. All data are presented as mean \pm SE. Statistical significance is defined as a $p$ value $<0.05$. For each variable, the mean of the data obtained between study hours 4 and 5 (period 1) were compared with the mean of those obtained between study hours 9 and 10 (period 2) using paired $t$ test. Thus, each subject was his or her own control. In addition, absolute changes in rates of glucose production, gluconeogenesis, and glycogenolysis were compared among the groups using ANOVA followed by Fisher's post hoc test and unpaired $t$ test.

\section{RESULTS}

\section{Infants Studied}

Tables 1 and 2 show demographics and clinical parameters for the infants included in the study groups. There were no differences among the groups.

\section{Blood Glucose Concentrations}

Blood glucose concentrations at start of the study did not differ significantly among the groups, $7.4 \pm 1.0 \mathrm{mM}$ in the "glucose alone" group, and $6.6 \pm 0.9$ and $7.3 \pm 1.0 \mathrm{mM}$ in infants receiving supplemental glycerol at 5 ("glucose + Glyc $5 ")$ and $10 \mu \mathrm{mol} / \mathrm{kg} \cdot \mathrm{min}$ ("glucose + Glyc 10"), respectively. Over the first $2 \mathrm{~h}$ of study, blood glucose concentrations fell in all infants in response to the reduced glucose infusion rate. From $2 \mathrm{~h}$ onward, a plateau (steady state) was reached and was maintained to the end of the study period in all groups, averaging $3.9 \pm 0.1 \mathrm{mM}$ ("glucose alone") and $3.5 \pm 0.1 \mathrm{mM}$ in both the "glucose + Glyc 5" and "glucose + Glyc 10" groups.

\section{Infants Receiving Glucose Alone}

Substrate and hormone concentrations. Blood glucose $(4.0 \pm$ 0.4 versus $3.8 \pm 0.3 \mathrm{mM}$ ) (ns), plasma glycerol $91 \pm 13$ versus $115 \pm 21 \mu \mathrm{M}$ (ns), and plasma insulin (4.2 \pm 0.7 versus $4.5 \pm 0.1$ $\mu \mathrm{U} / \mathrm{mL}$ ) (ns) concentrations remained unchanged between period 1 (4 and $5 \mathrm{~h}$ ) and period 2 (9 and $10 \mathrm{~h}$ ).

Glucose and glycerol kinetics. Between Period 1 and Period 2, total plasma appearance rates of glucose decreased from $29.6 \pm$ 1.2 to $24.8 \pm 1.3 \mu \mathrm{mol} / \mathrm{kg} \cdot \min (p=0.007)$, and glucose production rates decreased from $12.9 \pm 1.2$ to $7.4 \pm 0.9 \mu \mathrm{mol} / \mathrm{kg} \cdot \mathrm{min}(p$ $=0.001)$ (Fig. 1 and Table 3 ). The decline in glucose production rates was a result of decreased glycogenolysis, $7.8 \pm 1.2$ (period 1) versus $1.7 \pm 0.8 \mu \mathrm{mol} / \mathrm{kg} \cdot \min ($ period 2$)(p<0.001)$, that was not matched by an increase in gluconeogenesis, $5.1 \pm 0.6$ (period 1) versus $5.7 \pm 0.4 \mu \mathrm{mol} / \mathrm{kg} \cdot \mathrm{min}$ (period 2) (ns) (Fig. 2). For no known reason, two infants had higher glucose production rates (16.7 and $18.2 \mu \mathrm{mol} / \mathrm{kg} \cdot \mathrm{min})$ than the remaining six infants. Excluding these two infants' data decreases the mean value for the glucose production rate to $11.4 \pm 0.6 \mu \mathrm{mol} / \mathrm{kg} \cdot \mathrm{min}$, but does not change the statistical results (rates of glucose production decreased $p=0.006$, and gluconeogenesis did not change). Plasma glycerol appearance rates did not change between period 1 and period $2(7.1 \pm 1.5$ and $8.1 \pm 1.5 \mu \mathrm{mol} / \mathrm{kg} \cdot \mathrm{min}$, respectively $)$ (ns).

\section{Infants Receiving Supplemental Glycerol at $5 \mu \mathrm{mol} / \mathrm{kg} \cdot \mathrm{min}$}

Substrate and hormone concentrations. Plasma glycerol concentrations increased from $45 \pm 12($ period 1$)$ to $111 \pm 15$ $\mu \mathrm{M}($ period 2) $(p=0.005)$ in response to glycerol infused at 5 $\mu \mathrm{mol} / \mathrm{kg} \cdot \mathrm{min}$.

However, neither blood glucose, $3.4 \pm 0.4($ period 1) and $3.3 \pm 0.3 \mathrm{mM}($ period 2$)(\mathrm{ns})$, nor insulin, $4.6 \pm 1.3($ period 1$)$ and $4.2 \pm 1.1 \mu \mathrm{U} / \mathrm{mL}$ (period 2) (ns), concentrations were affected by the glycerol infusion.

Glucose and glycerol kinetics. Plasma glycerol appearance rates increased from $2.68 \pm 0.99($ period 1$)$ to $5.89 \pm 0.37$ $\mu \mathrm{mol} / \mathrm{kg} \cdot \min ($ period 2) $(p=0.02)$ in response to a glycerol infusion rate of $5 \mu \mathrm{mol} / \mathrm{kg} \cdot \mathrm{min}$ (Table 3 ).

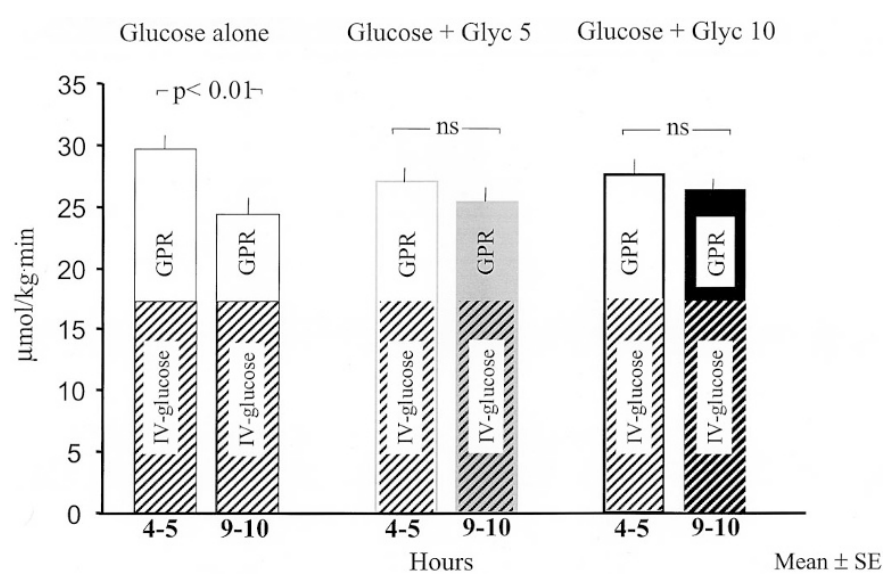

Figure 1. Rates of total plasma glucose appearance and glucose production. All infants received only glucose $(17 \mu \mathrm{mol} / \mathrm{kg} \cdot \mathrm{min})$ during period $1(4-5 \mathrm{~h})$. During period $2(9-10 \mathrm{~h})$, the "glucose alone" group received only glucose (17 $\mu \mathrm{mol} / \mathrm{kg} \cdot \mathrm{min})$, whereas the glycerol-supplemented groups had received glucose $(17 \mu \mathrm{mol} / \mathrm{kg} \cdot \mathrm{min})$ plus glycerol at either $5 \mu \mathrm{mol} / \mathrm{kg} \cdot \mathrm{min}$ ("glucose + Glyc $5 ")$ or at $10 \mu \mathrm{mol} / \mathrm{kg} \cdot \min$ ("glucose + Glyc $10 ") . P<0.01$ and $\mathrm{ns}$, respectively, refer to both rates of total plasma glucose appearance and glucose production 


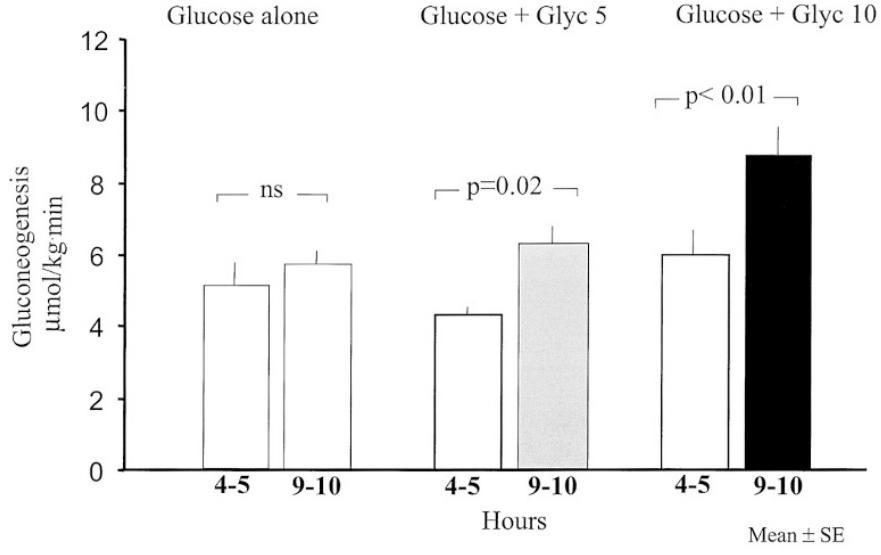

Figure 2. Gluconeogenesis. All infants received only glucose $(17 \mu \mathrm{mol} /$ $\mathrm{kg} \cdot \mathrm{min})$ during period $1(4-5 \mathrm{~h})$. During period $2(9-10 \mathrm{~h})$, the "glucose alone" group received only glucose $(17 \mu \mathrm{mol} / \mathrm{kg} \cdot \mathrm{min})$, whereas the glycerolsupplemented groups had received glucose $(17 \mu \mathrm{mol} / \mathrm{kg} \cdot \mathrm{min})$ plus glycerol at either $5 \mu \mathrm{mol} / \mathrm{kg} \cdot \mathrm{min}$ ("glucose + Glyc 5 ") or at $10 \mu \mathrm{mol} / \mathrm{kg} \cdot \mathrm{min}$ ("glucose + Glyc 10").

Neither total plasma appearance rates of glucose nor glucose production rates changed significantly over the 10 -h study period when glycerol was infused at $5 \mu \mathrm{mol} / \mathrm{kg} \cdot \mathrm{min}$ during the final $5 \mathrm{~h}$ ( $p=0.26$ for both variables) (Fig. 1). Glycogenolysis decreased from $5.5 \pm 1.2($ period 1$)$ to $2.0 \pm 0.8 \mu \mathrm{mol} / \mathrm{kg} \cdot \mathrm{min}($ period 2$)(p$ $=0.02)$, but glucose production rates were maintained because the rate of gluconeogenesis increased from $4.2 \pm 0.2($ period 1$)$ to $6.3 \pm 0.5 \mu \mathrm{mol} / \mathrm{kg} \cdot \min ($ period 2$)(p=0.02)($ Fig. 2).

\section{Infants Receiving Supplemental Glycerol at $10 \mu \mathrm{mol} / \mathrm{kg} \cdot \mathrm{min}$}

Substrate and hormone concentrations. Between period 1 and period 2, plasma glycerol concentrations increased from 40 \pm 3 to $189 \pm 21 \mu \mathrm{M}(p=0.001)$ in response to glycerol infused at $10 \mu \mathrm{mol} / \mathrm{kg} \cdot \mathrm{min}$, that is, the glycerol concentrations were significantly higher $(p=0.01)$ than during infusion of glycerol at $5 \mu \mathrm{mol} / \mathrm{kg} \cdot \mathrm{min}$.

As found with the lower glycerol infusion rate, concentrations of blood glucose, $3.4 \pm 0.3($ period 1$)$ and $3.5 \pm 0.3 \mathrm{mM}$ (period 2) (ns), and plasma insulin, $5.8 \pm 0.5($ period 1$)$ and 4.5 $\pm 0.5 \mu \mathrm{U} / \mathrm{mL}$ (period 2) (ns) were unaffected by glycerol infused at $10 \mu \mathrm{mol} / \mathrm{kg} \cdot \mathrm{min}$

Glucose and glycerol kinetics. Plasma glycerol appearance rates increased from $1.6 \pm 0.2($ period 1$)$ to $10.5 \pm 0.2 \mu \mathrm{mol} /$ $\mathrm{kg} \cdot \mathrm{min}$ (period 2) $(p<0.001)$ in response to glycerol at 10 $\mu \mathrm{mol} / \mathrm{kg} \cdot \mathrm{min}$, which is significantly higher $(p<0.0001)$ than during the infusion of glycerol at $5 \mu \mathrm{mol} / \mathrm{kg} \cdot \mathrm{min}$ (Table 3 ).

Neither total plasma appearance rates of glucose nor glucose production rates changed during the study period when glycerol was infused at $10 \mu \mathrm{mol} / \mathrm{kg} \cdot \mathrm{min}(p=0.23$ for both variables) (Fig. 1). As found with the lower glycerol infusion rate, the carbon source for glucose production changed in that glycogenolysis decreased from $4.4 \pm 1.1($ period 1$)$ to $0.3 \pm$ $0.7 \mu \mathrm{mol} / \mathrm{kg} \cdot \mathrm{min}($ period 2$)(p=0.001)$, whereas gluconeogenesis increased from $6.0 \pm 0.7$ (period 1) to $8.8 \pm 0.8$ $\mu \mathrm{mol} / \mathrm{kg} \cdot \min ($ period 2) $(p=0.002)$ (Fig. 2).
These studies were based on a paired study design. However, the results obtained from the paired studies were further analyzed by comparing the absolute changes in rates of glucose production, gluconeogenesis, and glycogenolysis among the groups (Fig. 3). Thus, ANOVA demonstrated that glucose production rates decreased in the infants receiving glucose alone compared with those who received supplemental glycerol at $5(p=0.03)$ as well as $10 \mu \mathrm{mol} / \mathrm{kg} \cdot \mathrm{min}(p=0.01)$ (Fig. $3)$. Further, infusion of glycerol at 5 and $10 \mu \mathrm{mol} / \mathrm{kg} \cdot \mathrm{min}$, respectively, increased gluconeogenesis, $p=0.04$ and $p=$ 0.008 , respectively (Fig. 3). Nonetheless, the magnitude of the increase in gluconeogenesis was not different between infants receiving glycerol at 5 and $10 \mu \mathrm{mol} / \mathrm{kg} \cdot \mathrm{min}$, respectively.

Glycogenolysis decreased to the same extent in all three groups (Fig. 3).

\section{DISCUSSION}

This study clearly demonstrates that parenteral glycerol alone enhances gluconeogenesis and attenuates timedependent decrease in glucose production in premature infants receiving glucose at one half of basal glucose turnover rates. In infants receiving glucose alone, glucose production rates decreased significantly over the 10 -h study period as a result of reduced glycogenolysis and no change in gluconeogenesis. The infants were, however, able to maintain euglycemia during the course of the study by decreasing their glucose utilization rate. In contrast, infants receiving supplemental glycerol maintained glucose production (despite comparable reduction of glycogenolysis) by increasing gluconeogenesis.

Although rates of glucose production measured during period 1, i.e. when all infants received glucose alone at 17 $\mu \mathrm{mol} / \mathrm{kg} \cdot \mathrm{min}$, did not differ significantly among the three study groups, two infants in the "glucose alone" group had higher glucose production rates (16.7 and $18.2 \mu \mathrm{mol} / \mathrm{kg} \cdot \mathrm{min})$ than the remaining six infants in this group $(n=6 ; 11.4 \pm 0.6$ $\mu \mathrm{mol} / \mathrm{kg} \cdot \mathrm{min})$. There were no obvious reasons for the higher glucose production rates in these infants, and the values are

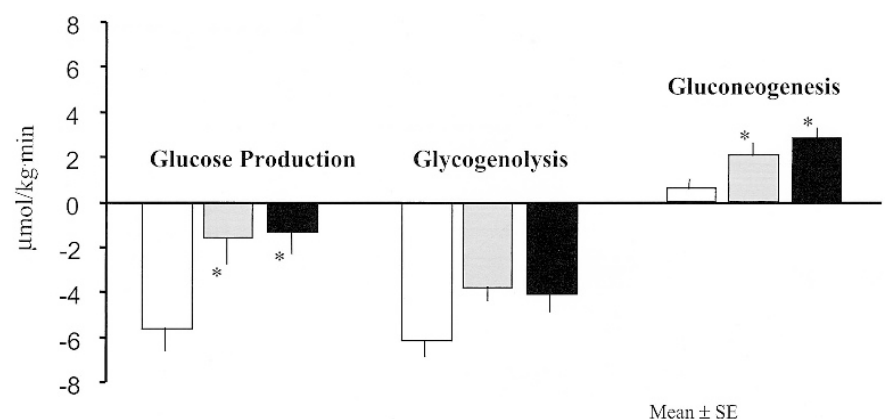

Figure 3. Absolute changes in rates of glucose production, glycogenolysis and gluconeogenesis during infusion of glucose alone and supplemental glycerol. Changes in rates of glucose production, glycogenolysis, and gluconeogenesis occurring between period 1 and period 2 in infants receiving only glucose during the 10-h study ("glucose alone") and in infants receiving supplemental glycerol at 5 ("glucose + Glyc 5 ") or $10 \mu \mathrm{mol} / \mathrm{kg} \cdot \mathrm{min}$ ("glucose + Glyc 10") during the final $5 \mathrm{~h}$ of the 10-h study. "Glucose alone" group (open bars); "glucose + Glyc 5" group (shaded bars); "glucose + Glyc 10" group (solid bars). ${ }^{*} p<0.05$ for "glucose alone" $v$ s "glucose + Glyc 5 " and "glucose alone" vs "glucose + Glyc 10." 
within the range previously reported by us and others in comparable infants $(5,34,35)$. Therefore, it would be inappropriate to exclude these infants. In addition, were we to have excluded these specific infants' data, neither the results of the statistical analyses (rates of glucose production decreased significantly at a $p$ value of 0.006 , and gluconeogenesis did not change) nor the conclusions would have changed.

The effects of glycerol were not directly proportional to the infused rates of glycerol. Theoretically, 5 and $10 \mu \mathrm{mol} / \mathrm{kg} \cdot \mathrm{min}$ of glycerol could yield 2.5 and $5 \mu \mathrm{mol} / \mathrm{kg} \cdot \mathrm{min}$ of glucose, respectively. Infusion of glycerol at $5 \mu \mathrm{mol} / \mathrm{kg} \cdot \mathrm{min}$ increased gluconeogenesis by $2 \mu \mathrm{mol} / \mathrm{kg} \cdot \mathrm{min}$ (i.e. $80 \%$ of the theoretical maximal value), whereas during infusion of $10 \mu \mathrm{mol} / \mathrm{kg} \cdot \mathrm{min}$ of glycerol, gluconeogenesis increased by $2.8 \mu \mathrm{mol} / \mathrm{kg} \cdot \min ($ i.e. $56 \%$ of the theoretical maximal value). This suggests that the ability of glycerol to increase gluconeogenesis approaches a maximum at $5 \mu \mathrm{mol} / \mathrm{kg} \cdot \mathrm{min}$.

We and others have demonstrated that endogenous glycerol contributes significantly to glucose production during the first hours of life in term infants (15-17). Further, very premature infants were also capable of generating glycerol via hydrolysis of their small fat stores and converting this glycerol to glucose, although the rates of glycerol turnover and conversion to glucose were more variable than those obtained in term infants $(17,18)$. The glycerol turnover rates observed during period 1 in the three groups of infants included in the present study were all within the range demonstrated in previous studies $(17,18)$. We have also previously demonstrated that in infants receiving a continuous supplementation of Intralipid, rates of gluconeogenesis were similar to those obtained after $5 \mathrm{~h}$ of glycerol infusion in the present study. In the Intralipid-infused infants, glycerol accounted for about two thirds of total gluconeogenesis $(7,36)$. Collectively, the results from the present and previous studies clearly demonstrate that glycerol is the primary gluconeogenic substrate in parenterally fed premature infants under these study conditions. Further, our data suggest that Intralipid supports gluconeogenesis primarily via its glycerol component.

In summary, we demonstrate that in premature infants receiving reduced glucose supply, intravenouse infusion of glycerol both enhances gluconeogenesis and attenuates the timedependent decline in glucose production observed in infants receiving reduced glucose supply alone.

Acknowledgments. The author thanks Drs. Dennis M. Bier and Morey W. Haymond at the Children's Nutrition Research Center, Houston, TX, for invaluable help and advice in designing this study, interpreting the results as well as in preparing this manuscript; Cindy Bryant, Pamela Burns, Ellen Newton, Pamela Gordon, and Cindy Clarke for excellent assistance; the pharmacist at Texas Children's Hospital for mixing TPN and preparing isotope solutions; and Dr. Richard Schanler and the staff of the neonatal intensive care unit for professional collaboration.

\section{REFERENCES}

1. Guyer B, Hoyert DL, Martin JA, Ventura SJ, MacDorman MF, Strobino DM 1991 Annual summary of vital statistics-1998. Pediatrics 104:1229-1246

2. Schanler RJ, Shulman RJ, Lau C, Smith EO, Heitkemper MM 1999 Feeding strategies for premature infants: randomized trial of gastrointestinal priming and tube-feeding method. Pediatrics 103:492-493
3. Kennedy KA, Tyson JE, Chamnanvanikij S 2002 Early versus delayed initiation of progressive enteral feedings for parenterally fed low birth weight or preterm infants (Cochrane Review). In: The Cochrane Library, Issue 4. Update Software, Oxford, UK

4. Gruenwald P, Minh HN 1960 Evaluation of body and organ weights in perinatal pathology. I. Normal standards derived from autopsies. Am J Clin Pathol 34:247-253

5. Bier DM, Leake RD, Haymond MW, Arnold KJ, Gruenke LD, Sperling MA, Kipnis DM 1977 Measurement of "true" glucose production rates in infancy and childhood with 6,6 - dideuteroglucose. Diabetes 26:1016-1023

6. Haymond MW, Sunehag AL 2000 The reciprocal pool model for the measurement of gluconeogenesis using [U- $\left.{ }^{13} \mathrm{C}\right]$ glucose. Am J Physiol 278:E140-E145

7. Sunehag AL, Haymond MW, Schanler RJ, Reeds PJ, Bier DM 1999 Gluconeogenesis in very low birth weight infants receiving total parenteral nutrition. Diabetes 48:791-800

8. Dweck HS, Cassady G 1974 Glucose intolerance in infants of very low birth weight I. Incidence of hyperglycemia in infants of birth weights 1100 grams or less. Pediatrics 53:189-195

9. Lilien LD, Rosenfield RL, Baccaro MM, Pildes R 1979 Hyperglycemia in stressed small premature neonates. J Pediatr 94:454-459

10. Miranda LE, Dweck HS 1977 Perinatal glucose homeostasis: the unique character of hyperglycemia and hypoglycemia in infants of very low birth weight. Clin Perinatol 4:351-365

11. Pildes RS 1986 Neonatal hyperglycemia. J Pediatr 109:905-907

12. Wu S, Srinivasan G, Pildes RS 1990 Plasma glucose $(\mathrm{G})$ values during the first month of life in infants $<1000$ gm. Pediatr Res 27:231A(abstr)

13. Kalhan SC, Parimi P, Van Beek R, Gilfillan C, Saker F, Gruca L, Sauer PJJ 2001 Estimation of gluconeogenesis in newborn infants. Am J Physiol Endocrinol Metab 281:E991-E997

14. Frazer TE, Karl IE, Hillman LS, Bier DM 1981 Direct measurement of gluconeogenesis from $2,3-{ }^{13} \mathrm{C}_{2}$ alanine in the human neonate. Am J Physiol 240:E615-E621

15. Bougnères PF, Karl IE, Hillman LS, Bier DM 1982 Lipid transport in the human newborn. Palmitate and glycerol turnover and the contribution of glycerol to neonatal hepatic glucose output. J Clin Invest 70:262-270

16. Patel D, Kalhan S 1992 Glycerol metabolism and triglyceride-fatty acid cycling in the newborn: effects of maternal diabetes and intrauterine growth retardation. Pediatr Res 31:52-58

17. Sunehag A, Gustafsson J, Ewald U 1996 Glycerol carbon contributes to hepatic glucose production during the first eight hours in healthy, term infants. Acta Paediatr 85:1339-1343

18. Sunehag A, Ewald U, Gustafsson J 1996 Extremely preterm infants ( $<28$ weeks) are capable of gluconeogenesis from glycerol on their first day of life. Pediatr Res 36:550-557

19. Yunis KA, Oh W, Kalhan S, Cowett RM 1992 Glucose kinetics following administration of an intravenous fat emulsion to low birth weight neonates. Am J Physiol 263:E844-E849

20. Vileisis RA, Cowett RM, Oh W 1982 Glycemic response to lipid infusion in the premature neonate. J Pediatr 100:108-112

21. Gilbertson N, Kovar IZ, Cox DJ, Crowe L, Palmer NT 1991 Introduction of intravenous lipid administration on the first day of life in the very low birth weight neonate. J Pediatr 119:615-623

22. Savich RD, Finley SL, Ogata ES 1988 Intravenous lipid and amino acids briskly increase plasma glucose concentrations in small premature infants. Am J Perinatol 5:201-205

23. Ballard JL, Khoury JC, Wedig K, Wang L, Eilers-Walsman BL, Lipp R 1991 New Ballard score, expanded to include extremely premature infants. J Pediatr 119:417-423

24. Lubchenco LO, Hansman C, Dessler M, Boyd E 1963 Intrauterine growth as estimated from live born birth-weight data at 24 to 42 weeks of gestation. Pediatrics 32:793-800

25. PJ, Carnielli VP, Sulkers EJ, van Goudoever JB 1994 Substrate utilization during the first week of life. Acta Paediatr Suppl 405:49-53

26. Micheli JL, Pfister R, Junod S, Laubscher B, Tolsa JF, Schutz Y, Calame A 1994 Water, energy and early postnatal growth in preterm infants. Acta Paediatr Suppl 405:35-42

27. TH, Vong SK 1996 Definition of neonatal hypoglycemia: is there a change? J Pediatr Child Health 32:302-305

28. Cornblath M, Ichord R 2000 Hypoglycemia in the neonate. Semin Perinatol 24:136-149

29. Kalhan S, Peter-Wohl S 2000 Hypoglycemia: what is it for the neonate? Am J Perinatol 17:11-18

30. Sunehag AL, Clarke L, Bier DM, Haymond MW $2001\left[\mathrm{U}_{-}{ }^{13} \mathrm{C}\right]$ glucose MIDA provides accurate measures of gluconeogenesis, is easy to perform and requires only small blood sample volumes. Diabetes 50:A65

31. Landau BR, Wahren J, Chandramouli V, Schumann WC, Ekberg K, Kalhan SC 1996 Contributions of gluconeogenesis to glucose production in the fasted state. J Clin Invest 98:378-385

32. Bier DM, Arnold KJ, Sherman WR, Holland WH, Holmes WF, Kipnis DM 1977 In vivo measurement of glucose and alanine metabolism with stable isotope tracers. Diabetes 26:1005-1015

33. Bougnères PF 1987 Stable isotope tracers and the determination of fuel fluxes in newborn infants. Biol Neonate 2:87-96

34. Sunehag A, Ewald U, Larsson A, Gustafsson J 1993 Glucose production rate in extremely immature neonates $(<28 \mathrm{w})$ studied by use of deuterated glucose. Pediatr Res 33:97-100

35. Tyrala EE, Chen X, Boden G 1994 Glucose metabolism in the infant weighing less than 1100 grams. J Pediatr 125:283-287

36. Sunehag AL, Haymond MW, Schanler RJ, Bier DM 2000 Parenteral lipids are important for supporting gluconeogenesis in very low birth weight infants. Pediatr Res 47:298A(abstr) 